\title{
Spirituality at Work: The Role of Spirituality Dimensions in Fostering Organizational Commitment
}

\author{
Sewwandi D.K. \\ The Open University of Sri Lanka \\ damunigeks88@gmail.com
}

\begin{abstract}
Organizational Commitment is one of the key determinants of organizational success. This knowledge era where Human resource is considered as the main strategic resource demands the full potential and commitment of the work force to win an edge over competition. Such commitment can no longer promote through traditional strategies alone but can only be fostered when conditions are available for employees to bring their 'whole self'-physical, mental and spiritual selves- to work place. Hence, call for spiritual values at work is increasing as employees seek opportunities for enriched work performed within the context of an organizational community along with personal and work goal congruence. Organizational commitment when fostered through these spiritual dimensions will be much consistent and long-lasting than temporary attachment generated through time- to- time material rewards. Hence, this conceptual paper aims at surfacing the grounds within which these two concepts can be linked for the betterment of the organization and its stakeholders.
\end{abstract}

Keywords: Organizational Commitment, Workplace Spirituality

Copyright: (C) 2018 D.K. Sewwandi. This is an open access article distributed under the Creative Commons Attribution License, which permits unrestricted use, distribution, and reproduction in any medium, provided the original work is properly cited.

Correspondence: damunigeks88@gmail.com

ORCID of author: https://orcid.org/0000-0003-1790-5490

DOI: http://10.4038/kjm.v7i2.7575 


\section{Introduction}

For years organizational success has always been viewed within the boundaries of economic and financial outcomes and inputs. Organizational performance was linked with the material success of the company in various quantifiable aspects. Many empirical studies have been conducted to measure the impact of such economic and financial aspects on organizational performance, yet studies that touch the spiritual grounds are scarce. However as per Ashmos \& Duchon (2000) there is increasing evidence that a major transformation is occurring in many organizations. The organizations once seen as rational systems are making room for spiritual dimensions. The Wall street journal (as cited in Ashmos \& Duchon, 2000) identifies a spiritual dimension as a dimension which has less to do with rules and order and more to do with meaning, purpose, and sense of community. It is an initiative to improve the ethical climate of the business (Polly, Vora $\&$ SubbaNarasimha, 2005).

In any organization, its employees are the main asset which handles every operation within the organization. There is a common belief that employees can always be retained within the organization by only providing them with monetary and other physical rewards. This notion is becoming outdated with the emerging concerns on the spiritual aspect expected by the employees from their organizations. In this perspective, organizations are considered as a collection of individuals with spirits nurtured by the work itself rather than external incentives. They are increasingly expecting a value for the work they perform, recognition to their effort, a feeling of belongingness to the organization and peers and opportunities for their mental wellbeing. Therefore, workplace spirituality has gained much attention of the business world in today's context. Organizations are seeking ways to sur- face the full potential of their employees, thus do not limit to hand and brain work.

With this conceptual study it is expected to join the line of research which explores the connections of spirituality at work has with organizational behaviour of employees. Among many such behavioural variables this study is focused on organizational commitment which is considered as a key facet of organizational success. It is considered as a predictor of employee turnover and as an indicator of organizational effectiveness and performance. The focus of this study, which is the role of spiritual values in encouraging organizational commitment, has been highlighted in organization and management literature even though an adequate attention has not been received. As Rego \& Cunha (2008) phrased, in every individual, there is an emotional and spiritual man along with the rational man. When this spiritual aspect is not adequately addressed, organizations may adversely affect. If they facilitate meaningful work, expression of self, sense of community and value alignment in the work setting it will result in higher intuition and creativity, honesty and trust, reduced absenteeism and turn over, thus enhancing the attachment of the individual to the organization (Krishnakumar \& Neck, 2002; Rego \& Cunha, 2008). Empirical evidence is also available to suggest that more spirited companies have outperformed the less-spirited ones in terms of organizational performance. Therefore, incorporating spirituality in management agenda is essential (Rego \& Cunha, 2008) especially in modern organizational context where work is considered as the centerpiece of individuals' lives (Jurkiewicz \& Giacalone, 2004, Rego \& Cunha, 2008).

In the literature, antecedents of organizational commitment have been viewed in relation to different aspects of the individual and the work environment. According to Meyer \& Allen (1991), those 
are personal characteristics, organizational structure and work experience (Affective commitment), side bets and alternatives (Continuance commitment), socialization and organizational investments (Normative commitment). Similar factors were proposed by Steers, but rather in an integrative manner. According to Steers (1977), personal characteristics, job characteristics and work experience antecede committed behaviour of employees towards organization. When closely look at the sub components of these antecedents there are instances where spiritual values such as affiliation, self-expression at work surface as antecedents, yet only in few research studies and with an inadequate emphasis.

In such a context, this paper mainly aims at providing a new perspective to understand the occurrence of organizational commitment. It calls for management to divert their sole focus from material and economic orientation on the organizational aspects toward an understanding of the organization as a collection of individuals with spirits. To date, limited number of research studies available which consider spirituality as a major antecedent of committed behaviour towards organizations. When considering the Sri Lankan context concept of spirituality at workplace is even more novel. Accordingly, another objective of this study is to contribute in filling the gap in management literature by providing a new conceptualization on the link between spirituality dimensions and organizational commitment. Apart from identification of the overall impact, it is also expected to identify how each dimension of workplace spirituality contributes in fostering each type of organizational commitment. The discussion begins with conceptualizing organizational commitment and workplace spirituality along with their dimensions and latter focus on identifying the linkages of commitment facets and spirituality dimensions to develop a conceptual model.

\section{Organizational Commitment}

Organizational commitment is one of the variables that are subjected to extensive research in management literature. As per the studies of Allen \& Meyer (1991) and Meyer \& Herscovitch, (2001), the broad interest in the area may be the effect of the construct on individual attitudes and behaviours such as turnover, intention to leave, organizational citizenship behaviour, attitude towards organizational change and maintaining organizational performance.

Over decades researchers have established relationships between organizational commitment and many other variables. When considering the workplace, organizational commitment has drawn the attention of many employers as it is considered as key to enhanced performance and employee retention in the organization (Adeyemo, 2007; Allen \& Meyer, 1990; Banyhamdan, Harrim \& Al-Qotop, 2012; Campbell \& Hwa, 2014; Jayarathne, 2016; Khatri \& Gupta, 2017; Shepherd \& Mathews, 2000; Wainaina, Iravo \& Waititu, 2014).

\section{Attitudinal and Behavioural Commit- ment}

There are two main perspectives of organizational commitment that can be observed in the literature; Attitudinal commitment and Behavioural commitment. Attitudinal commitment tend to focus on the organizational and individual goal congruence where the individual willing to identify his or her self with the organization and willing to continue his or her relationship with the same (Meyer \& Allen, 1991). Behavioural commitment on the other hand as per the studies of Mowday, Porter \& Dubin (as cited in Meyer \& Allen, 1991) follows the notion that behaviour of an individual is central to organizational commitment thus it is considered as "the process by which individuals become locked in to a certain 
organization and how they deal with this problem" p.62). According to Meyer \& Allen (1991), research to date on attitudinal commitment has largely focused on identifying the conditions for commitment development and its behavioural consequences whereas studies on behavioral commitment have their focus on conditions which result in repetitive behaviour and its influence on attitude change.

\section{Commitment Defined}

The attitudinal and behavioural nature of organizational commitment has led to diversified conceptualizations and measurement of the construct (Meyer \& Allen, 1991; Meyer \& Herscovitch, 2001). There are cases where commitment is identified as a uni-dimensional (Becker, 1960; Buchanan, 1974; Mowday, Steers \& Porter, 1979) construct while some others defined it as being multidimensional (Allen \& Meyer, 1990; Rego and
Cunha, 2008). A study by Meyer \& Herscovitch (2001) on commitment literature has explained how the object towards which the feeling of commitment is directed has generated different types of commitment. As per their analysis, definitions of commitment can be found in relation to job, occupation, goals, organizational change, strategy and organization. If the direction of commitment is job, it is defined as job commitment and if it is entire organization and its interactions, it is referred to as organizational commitment, etc.

In general, commitment can be defined as "...a force that binds an individual to a course of action of relevance to one or more targets" (Meyer \& Herscovitch, 2001, p. 301). It is a stabilizing force which provides direction to human behaviour when other conditions like equity do not exist (Scholl, 1981). Brown (1996) defines commitment as "an obliging force which requires that the person hon-

\section{Attitudinal Perspective}

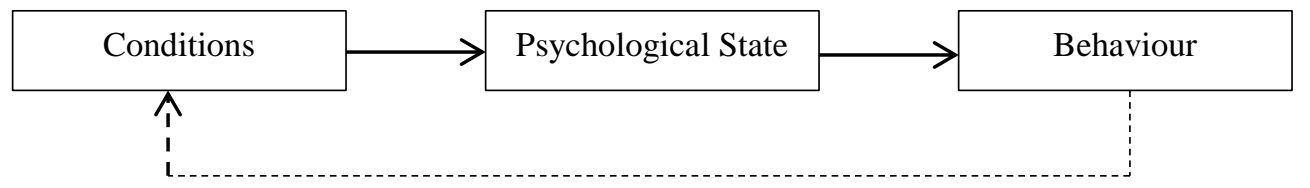

Behavioural Perspective

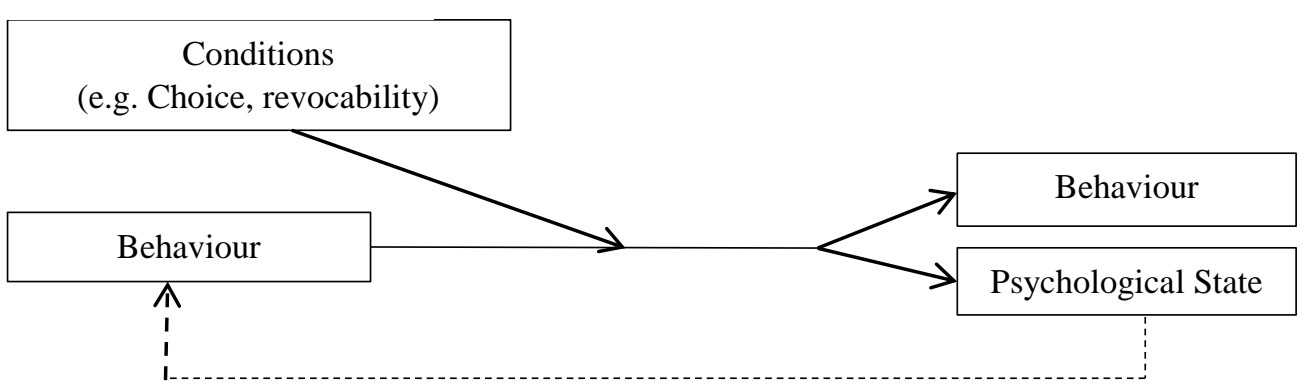

Fig. 1 The Attitudinal and Behavioural Perspectives on Organizational Commitment Source: Adapted from "A Three-Component Conceptualization of Organizational Commitment" by J.P. Meyer \& N.J. Allen, 1991, Human Resource Management Review, 1, p.63 
or the commitment, even in the face of fluctuating attitudes and whims." (p. 241). Accordingly, it is more an obligation irrespective of the individual's interests.

Commitment towards one's job is termed as job commitment which refers to an individual's psychological involvement to his or her job (Rusbult \& Farrell, 1983). The feeling of satisfaction or dissatisfaction is not relevant here when an individual is psychologically attached to do a particular job. Carson \& Bedeian (as cited in Meyer \& Herscovitch, 2001) distinguished occupational commitment from job commitment and termed it as "one's motivation to work in a chosen vocation" (p.302). Goal commitment occurs when the said attachment or involvement is directed towards achieving a particular goal rather than towards a job. It is referred to as one's determination of reaching a goal overtime and where such determination does not lower in the face of negative feedback (DeShon \& Landis, 1997; Locke, Latham \& Erez, 1988). As Weissbein, Plamondon \& Ford suggested (as cited in Meyer \& Herscovitch, 2001) even an individual can be committed to a particular strategy where that individual exerts effort to enact that strategy. For the purpose of this study, commitment towards one's organization is considered as it represents the attachment of a person towards the organization and his willingness to identify himself as a part of it.

\section{Conceptualizing Organizational Commitment}

Organizational commitment is often used interchangeably with the term commitment when applied to work setting. Allen $\&$ Meyer (2000) identified organizational commitment as "a psychological state that characterizes an employee's relationship with the organization and reduces the likelihood that he/she will leave it" (p. 59). In their definition, they have conceptualized organizational commitment as a state of mind. That particular mental state creates an attachment to the organization resulting in reduced turnover. Newstrom \& Davis (as cited in Dehaghi, Goodarzi \& Arazi, 2012) defined employee commitment as one's belief in the mission of the firm, willingness to extend effort in its accomplishment and intentions to continue working at the organization. Agreeing on the same, Motahari (as cited in Dehaghi et al., 2012) brought in a religious flavor to the commitment literature by defining it as the binding principles and philosophy or contract to which humans bound and believe in them. His definition is much in relation to Islamic perspective on commitment, yet it expresses the similar ideas of being loyal to the place where an individual belongs. Luthans (2006), the behavioural scientist brought in more behavioural view to commitment by defining it in three perspectives; a strong desire to remain a member of a particular organization, a willingness to exert high levels of effort on behalf of the organization and a definite belief in acceptance of the values and goals of the organization. Apart from the above definitions followings are few other definitions of organizational commitment as cited in the study of Meyer \& Herscovitch (2001, p.302).

"Organizational commitment is a bond or linking of the individual to the organization.” (Mathieu \& Zajac, 1990, p.171)

"It is a psychological state that binds the individual to the organization (i.e. makes turnover less likely." (Allen \& Meyer, 1990, p. 14)

“..the psychological attachment felt by the person for the organization; it will reflect the degree to which the individual internalizes or adopts characteristics or perspectives of the organization." (O’Reilly \& Chatman, 1986, p. 493) 
"..the totality of normative pressures to act in a way which meets organizational goals and interests." (Wiener, 1982, p.421)

When closely analyzed, all the above definitions encompass several common characteristics. (a) there is a bond to the organization, which is necessarily psychological (b) individuals adopt the values and ways of the organization and willing to be identified with the organization (c) willingness to exert efforts towards achieving organizational goals. The same is established by other several studies which believe that even though conceptualized differently, commitment has a common essence (Brown; 1996; Meyer \& Herscovitch, 2001). However, there exists a disagreement on the multidimensionality of organizational commitment as they are established upon diverse motives and strategies (Meyer \& Herscovitch, 2001).

Apart from the unidimensional conceptualization of organizational commitment, there are many multidimensional models that can be observed in the recent literature. In their study Meyer \& Herscovitch (2001) have complied several such multidimensional models by Angel and Perry (1981), O'Reilly and Chatman (1986), Panley and Gould (1988), Meyer and Allen (1991), Mayer and Schoorman (1992) and Jaros et al., (1993).

\section{Three Component model of Organiza- tional Commitment}

The three component model proposed by Allen \& Meyer (1990) is considered as one of the most quoted multidimensional models of organizational commitment. According to Meyer \& Herscovitch (2001) the difference between these three reflects the differences in mind-set towards commitment, thus focused on attitudinal commitment. These three mindsets are mutually exclusive hence considered as components rather than types of commitment. They do not correlate with each other, developed independently based on different antecedents and processes. We cannot see a person with a single type of commitment, yet an individual may have all these three variations in his or her commitment in varying degrees. Whatever the dominant component, it influences and reflected by one's behaviour. According to Meyer \& Allen (1990), employees with strong affective commitment remain because they want to, those with strong continuance commitment retain because they need to and those with strong normative commitment stay because they feel they ought to do so.

\section{Affective Commitment}

Affective component of organizational commitment is considered as the most prevalent approach to conceptualize organizational commitment. Most of the unidimesional models of commitment are based on this facet of commitment where it discusses about an emotional attachment to one's organization. This emotional attachment will lead to increase in employee morale and motivate them to willingly exert maximum contribution towards organizational success. This leads to reduced absenteeism and turnover, enhanced citizenship behaviour and ultimately higher organizational performance (Rego \& Cunha, 2008). According to Allen \& Meyer (1990), “.... an affective or emotional attachment to the organization such that the strongly committed individual identifies with, is involved in, and enjoys membership in, the organization" (p.2). The original view of the construct is forwarded by Kanter (as cited in Meyer \& Allen, 1990) as 'cohesion commitment' which is "the attachment of an individual's fund of affectivity and emotion to the group" (p.2). Most of the definitions of organizational commitment are in fact based on affective component of commitment as it explains the psychological attachment to the organization. 
Mowday et al. (as cited in Meyer \& Allen, 1991) have forwarded four antecedents of affective commitment; personal characteristics, structural characteristics, job-related characteristics and work experiences.

\section{Continuance Commitment}

Continuance component of organizational commitment is much similar to the concept of 'switching costs'. It is the commitment based on costs that employees associate with leaving the organization (Allen \& Meyer, 1990). For some authors affective component plays a minimal role in determining organizational commitment. For them what matters is the perception of the employees on costs associated with leaving the organization.

Studies of Becker, Farrell, and Rusbult (as cited in Meyer \& Allen, 1990) identified Continuance commitment as "a tendency to engage in consistent lines of activity based on the individual's recognition of the 'costs' (or lost side-bets) associated with discontinuing the activity" (p.3). As this component of commitment is based on the cost associated with leaving an organization, any fact that increases such cost can be taken as an antecedent of continuance commitment. In literature side-bets or investments and existence of alterative opportunities are considered as the predominant antecedents. These side-bets according to Becker (1960) can be either work related (losing a promotion, time and effort spent in learning non-transferable skills, losing seniority based privileges) or non-work related (disrupt personal relationships, family burden). However, the nature of the side-bets and their consequences can be varied according to individual.

\section{Normative Commitment}

Third facet of this commitment model is concerned with the obligatory attachment that an individual has towards his or her organization. Here, organizational commitment is viewed as "a belief about one's responsibility to the organization" (Allen \& Meyer, 1990). A comprehensive idea on commitment given by Wiener (1982) indicates the term itself is normative in nature. According to him, normative commitment is "the totality of internalized normative pressures to act in a way which meets organizational goals and interests and suggests that individu-

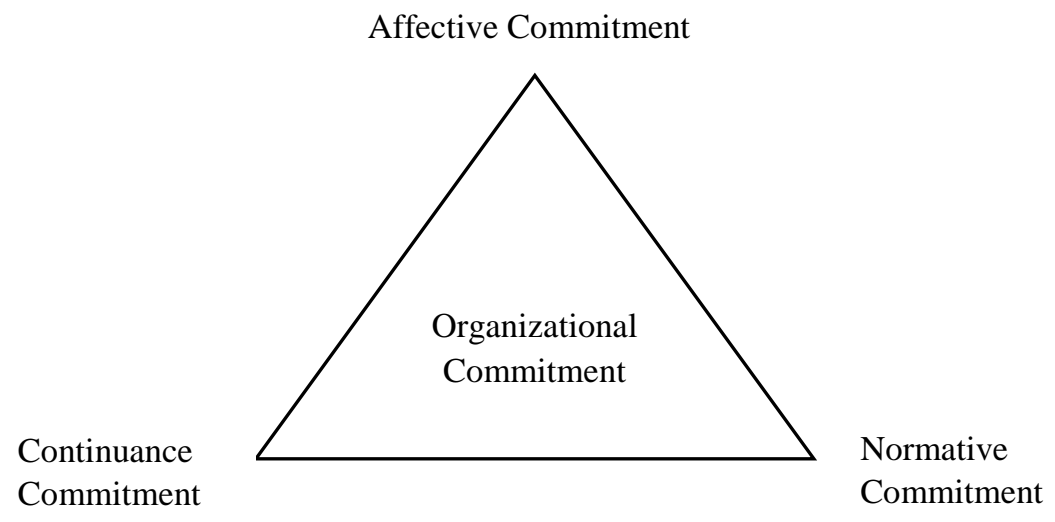

Fig. 2 The Three component model of Organizational Commitment

Source: Adapted from "The effect of spiritual values on employees' organizational commitment and its models" by M.R. Dehaghi, M. Goodarzi and Z.K. Arazi, 2012, Procedia-Social and Behavioural Sciences, 62, p.164 
als exhibit behaviours solely because they believe it is the right and moral thing to do" (p.421). Meyer \& Allen (1991) identified several sources that generate this normative pressures; familial or cultural pressures exist prior to enter to the organization, socialization process take place following entry, rewards in advance by the organization which automatically creates a bond and substantial costs incurred by the organization upon employment. According to Scholl (1981) these debts pose influence on the normal relationship between the employee and the organization and make the relationship imbalanced by making the employee feel obligated to stay with the organization irrespective of his or her original feelings towards the organization.

Figure 3 presents the summary of the above mentioned antecedents and outcomes of the three components of commitment. Each one of these components determines the probability of an employee retaining within an organization, subject to the nature of the mindset of the individual (Rego \& Cunha, 2008). According to Meyer \& Allen (1990), this model predicts that as affective commitment relates to the emotional bond of the individual, it leads to lower turnover, less absenteeism and improved performance. Employees with strong continuance commitment show tendency to contribute to the organizational success beyond what is expected to retain within the organization. Individuals with normative commitment may also want to give a positive contribution to the organization yet, not strong positive commitment as affective component. In summary, organizational commitment can be identified as the feeling of involvement and identification with one's organization (Steers, 1977). This is an attachment that is occurring as a result of an individual's emotional bond towards organization or due to an obligatory feeling for what is received by the organization or due to per- ceived costs of leaving the organization. Mostly commitment is a blend of all three, yet one dominates and decides the ultimate behaviour. For a more desirable outcome it is suggested to encourage affective and normative facets of commitment while discourage the instrumental or continuance commitment (Rego \& Cunha, 2008). Managers can foster the most desirable commitment facet within their employees by focusing on the antecedents of each commitment type and adjusting those organizational variables accordingly.

Organizational commitment has an extensive research history where job satisfaction is the only work attitude which has attracted attention of researchers than organizational commitment (Allen \& Meyer, 2000). It has been studied with numerous job related variables such as job satisfaction, job stress, motivation, citizenship behaviour, intention to leave, organizational performance, etc. Nevertheless, tenure within the organization or turnover has been the mostly studied behavioural variable with commitment which reflects connections to affective, continuance and normative components of commitment (Meyer \& Allen, 1991). As literature suggests, irrespective of the extensive research history of commitment, studies exploring the impact of spirituality at work on organizational commitment are limited given the fact that it is only recently that spirituality has gained the attention of scholars and practitioners in relation to workplace. As individual constructs there are considerable number of research available, yet evidence for formal studies including both these variables are limited (Rego \& Cunha, 2008). However, with the limited literature, the significant impact of having spiritual values on commitment of organizational members has been proven in diverse contexts and with diverse study samples. 


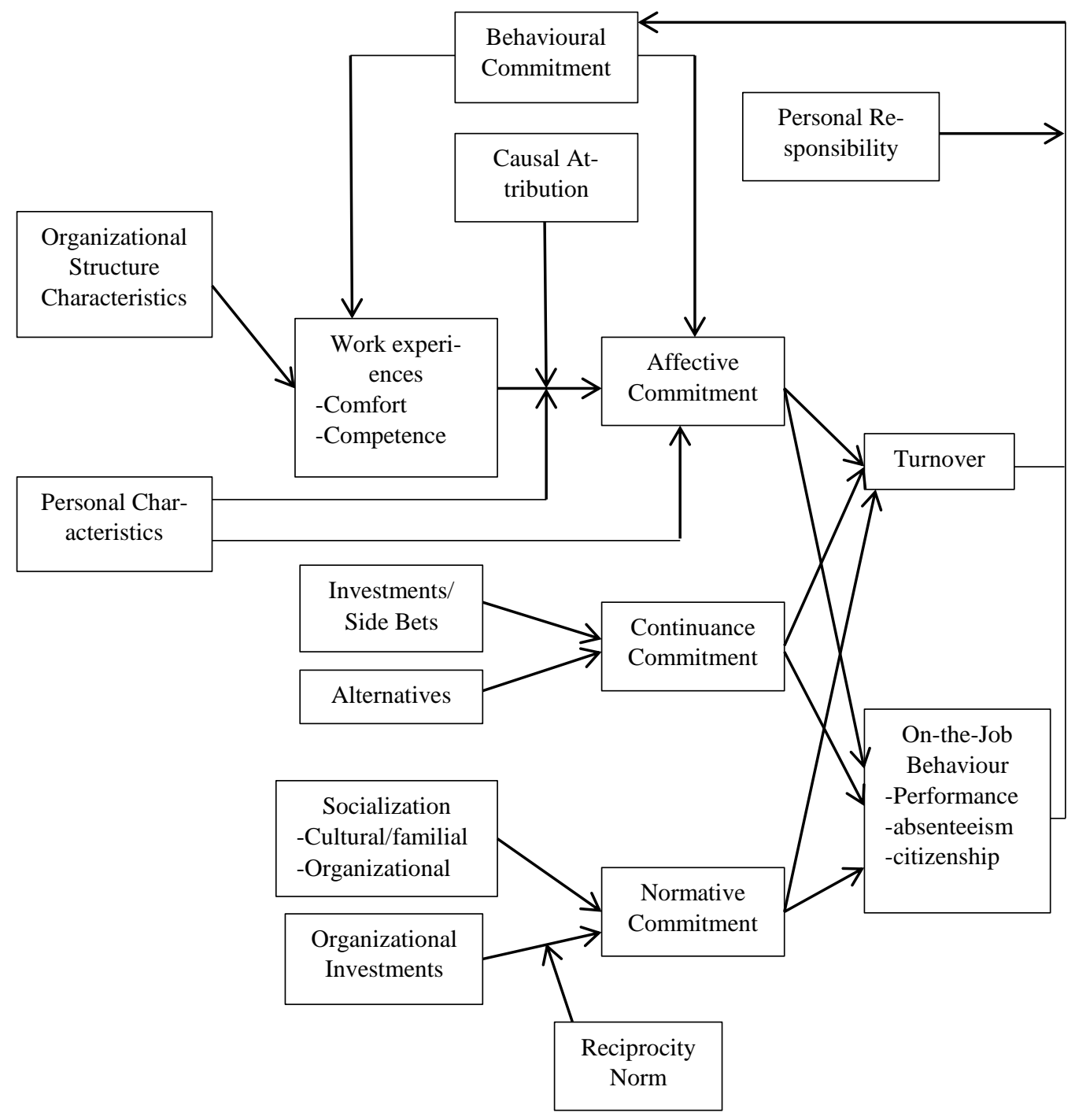

Fig. 3 A Three Component model of Organizational Commitment

(Source: Adapted from "A Three-Component Conceptualization of Organizational Commitment" by J.P. Meyer \& N.J. Allen, 1991, Human Resource Management Review, 1, p.63)

\section{Conceptualizing Workplace Spirituality}

Workplace spirituality, spirit at work or spirituality at work have been used interchangeably in literature when describing the inner force or energy that drives or motivates individuals beyond the obstacles they face. The term "spirit" reflects a connection of an individual with his or her self and with the entire universe where such connection is built upon a continuous search for purpose (Kinjerski \& Skrypnek, 2004). According to Myers (as cited in Kinjerski \& Skrypnek, 2004) it is "a continuing search for meaning and purpose in life; an appreciation for the depth of life; the expanse of the Universe, and natural forces which operate; a personal belief system" (p.28). When theo- 
rizing spirituality, it can be observed that the aspects of search for meaning and connectedness have been included often as main components or enabling conditions of spiritualty. The spirituality dimension of an individual goes beyond one's cognitive or emotional limits and creates an arena which guides the actions of individuals intuitively even in the absence of emotional support. Some might explain this as being divine force or some unexplainable energy within one's self, yet it is subjective upon the way one experience its presence (Kinjerski, Skrypnek, 2004).

Even though the concept of spirituality is new to workplace it is not new to human experience as it has been always embedded in religious traditions which encourage human being to search for meaning of life (Ashmos \& Duchon, 2000). Increasing value given by employees for meaningfulness of the work life over material aspects has opened up the platform for organizations to absorb spirituality into their work setting. Workplace spirituality by way of many definitions evident in the literature concerns about personal values and inner life aspirations of the individuals which can be fulfilled by engaging in the work itself and the sense of belongingness to the organization.

Given the number of studies on spirituality, a review of literature determines there is no widely accepted definition of spirituality at work (Duchon \& Plowman, 2005; Krishnakumar \& Neck, 2002; Milliman, Czaplewski, and Ferguson 2003; Rego \& Cunha, 2008). However, most of these definitions acknowledge that spirituality at work involves a sense of wholeness and connectedness at work and ascribes deeper values (Djafri \& Noordin, 2017). Workplace spirituality can be defined as the "recognition that employees have an inner life which nourishes and is nourished by meaningful work taking place in the context of a community"
(Ashmos \& Duchon, 2000, p.137). This definition is considered as one of the most quoted definitions of workplace spirituality and it highlighted inner life, meaningful work and community as the major constituents of a spiritual workplace. Similarly, Mitroff and Denton (as cited in Djafri \& Noordin, 2017) defined spirituality in the workplace as the desire to find one's ultimate purpose in life, develop a strong connection with either coworkers or other people associated with work, and be consistent with one's core beliefs and values of their organization. Even though it's quite similar to Ashmos \& Duchon's definition, Mitroff and Denton has paid a special attention to an alignment of personal and organizational values rather than on meaningful work. Giacolane \& Jurkiewicz (2003) have defined workplace spirituality as “ a framework of organizational values evidenced in the culture that promote employees' experience of transcendence through the work process, facilitating their sense of being connected to others in a way that provides feelings of completeness and joy"(p.129). They seem to include all the above components in defining workplace spiritualty. However, more or less usage of these main components of spirituality is evident in the literature depending on the focus and scope of study.

Controversially, Laabs (as cited in Rego $\&$ Cunha, 2008) brougt in vague idea on the concept of workplace spirituality by stating that "it is much easier to explain what spirituality is not than it is to define what it is" (p. 55). This concept imprecision has made some researchers of the area uncertain about the validity of the attention given to the concept. Rego \& Cunha (2008) forwarded arguments counter to the arguments by skeptics and explained three reasons validating the significance given to the concept. Firstly, as per Mitroff (as cited in Rego \& Cunha, 2008) imprecision is part of the phenomenon of spirituality itself. Secondly, re- 
searchers should not be discouraged to study a topic just because it is difficult to define or test empirically. Thirdly, as individuals have singular way to live their spirituality, researchers may disagree about what spirituality is and its measurements based on the feedback from the individuals.

Studies of Hart \& Brady; Judge; Sanders, Hopkins and Geroy, (as cited in Rego \& Cunha, 2008) and Pandey (2007) emphasized that irrespective of the difficulties in empirically measuring the construct, spirituality itself is a human need for individuals and it is a reality that should not be ignored by the society and its constituents.

\section{Spirituality vs. Religiosity}

The role of religion in spirituality is controversial. Many traditional proponents of spirituality holds the belief that spirituality is all about having religious value systems and beliefs within organizations while modern views in general believe that spirituality has its roots based in religion (Cavanagh, 1999). Even the term spirituality brings a feeling of a sacred, inner self-oriented to one's mind.

A study by Krishnakumar \& Neck (2002) has brought insight to various religious views on spiritualty. According to Naylor, Willimon, \& Osterberg (as cited in Krishnakumar \& Neck, 2002) Christians view spirituality as a divine call for work which is a part of the God's creation. Menon (as cited in Krishnakumar \& Neck, 2002) citing the sacred text "The Bhagavad Gita", explained that as per Hindus when work is considered, effort towards the goal is the most important as the result of such effort is provided by God. Buddhism, which itself is a philosophy of way of life, has many teachings on including spiritual values in work. According to Jacobson, (as cited in Krishnakumar \& Neck, 2002), hard work and devotion are considered as tools to modify a person's life in Buddhism. The ultimate result of such commitment will be an enriched life and work. When considering the modern conceptualizations of spirituality, enrichment in work life or in other words meaningful work life is considered as one of the major components of workplace spirituality.

Yousef (2000), brining on Islamic views on workplace spirituality proposed that according to Islamic Work Ethics, commitment is considered as the key in workplace and it facilitate organizational change as well. According to him, when employees are committed toward the organization, they are flexible to adapt to changes.

Even though most of the religious beliefs view the spiritual values in workplace from an individual's perspective, there are other ancient religions like Taoism and Confucianism which emphasized the concept of spirituality in terms of group behaviours. They place much importance in togetherness and teamwork as spiritual values in workplace (Krishnakumar \& Neck, 2002).

Having considered the different religious views on applying spirituality in work setting, many would think that workplace spirituality is necessarily related with holding some religious value within the organization. However, it is far more than merely complying with a specific religious belief. It does have religious imagery grounded behind the concept, yet it is not all about making someone to accept some religious values. It is more based on an individual's personal values and philosophy.

However, spirituality at work, despite religious imagery; is not about religion or conversion, or about getting people to accept a specific belief system. Rather, it is about employees who understand themselves as spiritual beings whose souls need nourishment at work. (Ashmos \& Duchon, 2000, p. 135) 
Supporting the same, Graber (as cited in Krishnakumar \& Neck, 2002) has argued that spirituality does not relate to formal and ceremonial connotations of religion and it is non-denominational, nonhierarchical, and non-ecclesiastical. It is a search of meaning or fulfillment within one's self irrespective of religion. Accordingly it can be suggested that religion cannot be separated totally from the concept of spirituality as our inner values or self-concept is more or less shaped by our religious values. The means we utilize to search for meaning in life may be the teachings that we absorbed by way of our religions. Even when we encounter some force that is beyond our control or explanation we tend to relate it to the divine powers we aspire. This establishes the ground that both religion and spirituality has common threads. However, talking about religion or highlighting religion within the workplace is considered as inappropriate by many authors, yet they encourage the discussions on spirituality at work (Kinjerski \& Skrypnek, 2004) considering it as one of the emerging roots for organizational success especially in the modern work organization.

Dehaghi, et al. (2012) discussed about two components of spirituality; Vertical and Horizontal where 'vertical' component is a desire to transcend the individual ego or self-esteem and 'horizontal' component being the desire to be of service to other humans and the planet. These two perspectives demonstrate an internal and external orientation to the construct of spirituality respectively. Examples for vertical spirituality include; meditation time at the beginning of the meetings, retreat or spiritual training time set aside for employees, appropriate accommodation of employees' prayer practices, etc. whereas horizontal spirituality is reflected by caring behaviours among co-workers, a social responsibility orientation, strong service commitments, etc. (Dehaghi et al., 2012).

\section{Workplace Spirituality Dimensions}

Even though, spirituality is a construct that is within the human nature, it is not much subjected to empirical research to properly conceptualize or measure. A study conducted by of Ashmos and Duchon is considered as a milestone in conceptualization and measurement of this psychological state using three levels of analysis; Individual, work unit and organizational. According to Ashmos \& Duchon (2000), workplace spirituality has three components: the inner life, meaningfulness of work and sense of connection and community. Thus, if an individual perceives a relationship of inner life to their work, find joy and meaningfulness in work and see him or her as a part of a trusting community, it enhances the spirituality at work of that individual. As a result of principle component factor analysis of above three components in all three levels of analysis Ashmos and Duchon identified seven dimensions of workplace spirituality; condition for community, meaning at work, Inner life (Individual Level), work unit community, positive work unit values (Work unit/Group Level), organization values and alignment of individual and organization (Organizational Level).

However, as spirituality is considered as a personal construct, Ashmos \& Duchon (2000) concluded that it is much difficult to measure in work unit and organizational levels as they are more abstract concepts than the individual level. Milliman et al. in their study on the impact of spirituality dimensions on five different work attitudes, have used only three from the above seven factors. Milliman et al. (2003) has forwarded three justifications for their selectivity. First, those three dimensions were considered as most important in many prior studies and represent employee involvement. Second, transcendent aspect of spirituality was ignored as it seems more personal to individuals' lives. Third, selection of three 
dimensions facilitated their intention for much parsimonious study. Accordingly, meaningful work, sense of community and alignment of work and organizational values representing each level of analysis were subjected to the study.

When deciding on the spirituality dimensions for the present study, dimensions that are similar to those of Milliman et al. have been considered based on their justifications. Yet, opportunity for inner life has been taken in to the model. It followed three reasons. (a)The aspect of inner life is too critical to ignore as it is more or less embedded in definitions of spirituality (b) Spirituality begins with the understanding on one's inner self which then directs to understanding the outer life (c) Eastern cultures including Sri Lanka place more value to the spiritual aspect of life than those in Western countries where these models were initially developed.
Rego \& Cunha (2008) used five dimensions of workplace spirituality; Team's sense of community, alignment between organizational and individual values, sense of contribution to the community, sense of enjoyment at work and opportunities for inner life in their investigation on the impact of workplace spirituality on organizational commitment. Inner life was considered as a dimension here other than those used by Milliman et al. as it was included in many definitions of workplace spirituality (Rego \& Cunha, 2008). A recent study by Liu \& Robertson (2011) has conceptualized a new model of three factors which they consider as correlated but distinct from each other. They are interconnection with a higher power, interconnection with human beings and interconnection with nature and all living beings. When closely analyzed, these three factors reflect the inner life and sense of connectedness dimensions used by Ashmos \& Duchon

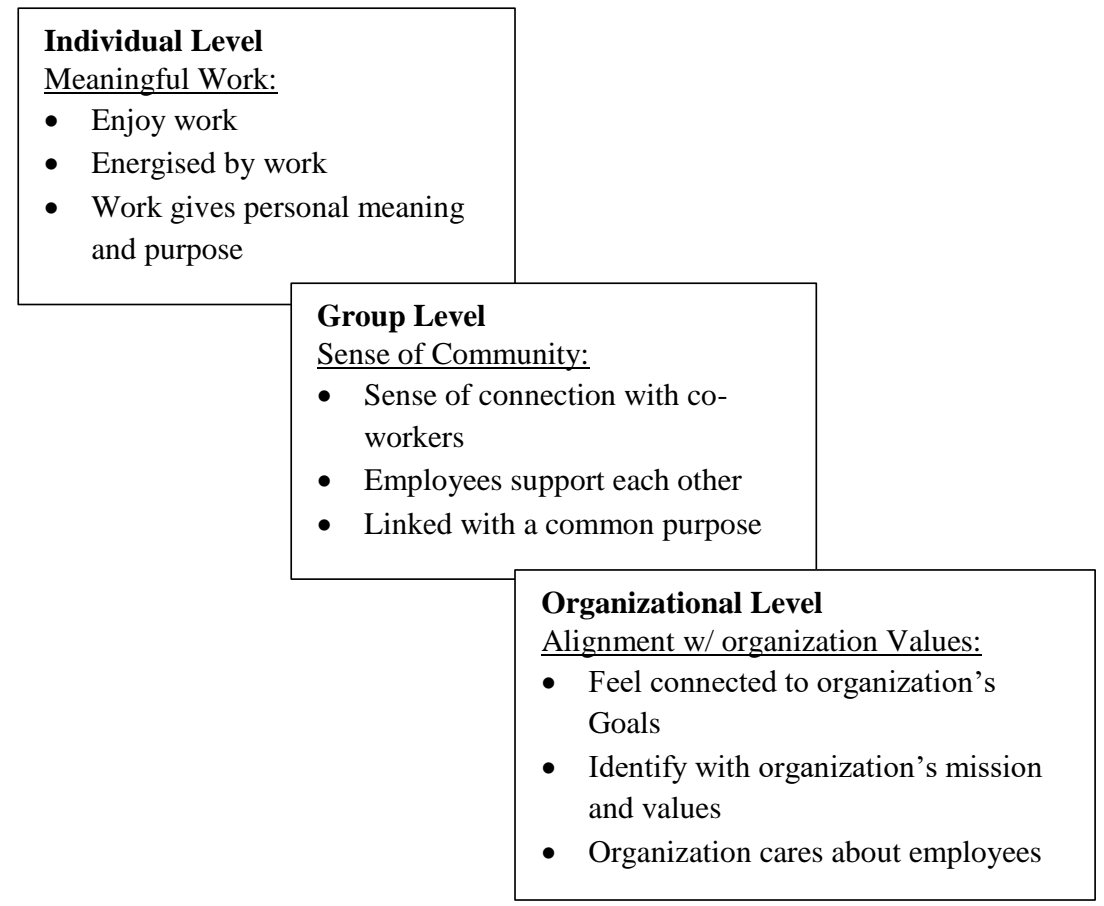

Fig.4 Conceptualizing spirituality in the workplace

Source: Adapted from "Workplace Spirituality and employee work attitudes: An exploratory empirical assessment” by J. Milliman, A.J. Czaplewski and J. Ferguson, 2003, Journal of

Organizational Change Management, 16(4), p. 428

Kelaniya Journal of Management | 2018 | Vol. 07 | Issue 02 | Page 27 
(2000), Milliman et al. (2003) and Rego and Cunha (2008).

Apart from different conceptualizations for measuring spirituality at work, there are different ways in which people experience or perceive the existence of spiritual values within the workplace. Fleming (as cited in Vasconcelos, 2018) has identified commonality/diversity, foreign but friendly terrain, personal belief versus organizational obligation, experience and expression of workplace spirituality and reflection-in-action and spiritual practice both personal and corporate levels as five ways in which people conceptualize workplace spirituality. Kinjerski and Skrypneck (2006b) found seven factors that foster employees' spirits at workplace such as inspiring leadership and mentorship, strong organizational foundation, organizational integrity, positive workplace culture and space, sense of community among members, opportunities for personal fulfillment, continuous learning and development, and appreciation and regard for employees and their contribution. Twelve core themes, namely; trust, openness, kindness, honesty, moral and ethics, a sense of peace and harmony, aesthetically pleasing work environment, team orientation, understanding, faith in God, respect and truth were found in a study by Marques, Dhiman and King in 2007 which reflect spiritualty within workplace. Similar themes were there among thirty four core themes which were identified by Vasconcelos in 2013 as to how Brazilian employees perceive spirituality (Vasconcelos, 2018).

\section{Inner life}

This can be considered as the transcendence aspect of workplace spirituality which permeates the physical and intellectual dimensions of an individual. It is acknowledging the existence of one's soul power and using that power to live a satisfying life (Ashmos \& Duchon,
1990). As Fox phrased it (cited in Ashmos \& Duchon, 1990), understanding spirituality at work starts with this acknowledgement and nourishment of which leads to a more productive and meaningful outer life. When individuals come to work, their values, beliefs, opinions on good and bad, right and wrong, their desires, life expectations also comes along with them. They constitute what is called as "whole self" of a person. However, there may be barriers to express most aspects of one's self in a workplace within the organizational red tape, especially spiritual self.

When considering the organizational behaviour literature, two constructs can be viewed as related to the presence of inner life: individual identity and social identity (Duchon \& Plowman, 2005). Individual identity is the expression of or inner view of one's self which Shamir (as cited in Duchon \& Plowman, 2005) phrased as the "self-concept". As the theory suggests when there is a high congruence among the job, its context and the person's selfconcept, work becomes motivating as it enables the expression of spiritual identity. However, as Shamir (as cited in Duchon \& Plowman, 2005) argued, this is highly subjective as people who are highly instrumentally motivated may not be so responsive for the opportunities for spiritual identity or self-expression at work.

Social identity occurs through affiliations among members within a work unit or an organization. These affiliations or group membership is required for an individual to express and understand themselves (Duchon \& Plowman, 2005). In the terminology of Dehaghi et al., these two constructs can be considered as connotations for vertical and horizontal spirituality.

In contemporary workplace, there is an increasing trend that people include spiritual self in to the whole self and consider 
it as one of the important dimensions of work life (Duchon \& Plowman, 2005). An organization which recognizes it as encouraging spirituality should view itself as a collection of individuals with minds and spirits where development of latter result in the development of former (Ashmos \& Duchon, 1990). As put forward by Duchon \& Plowman (2005),

An important dimension of spirituality at work is the notion that employees have spiritual needs (i.e. inner life), just as they have physical, emotional, and cognitive needs, and these needs don't get left at home when they come to work. (p. 811)

\section{Meaningful work}

Even though the term spirituality is new to workplace, searching meaning or purpose in work is not new (Ashmos \& Duchon, 2000). It had been considered as a fundamental aspect in employee work life since the human relations movement started with Hawthorn experiments at Western Electrical Company. This involves employee engaging in work which gives them a deep sense of meaning and purpose (Ashmos \& Duchon, 2000; Milliman et al., 2003). Terkel, (as cited in Ashmos \& Duchon, 2000) has termed this to show how it differs from the search for material aspects of work life,

Work must be about a search, too, for daily meaning as well as daily bread, for recognition as well as cash, for astonishment rather than torpor; in short, for a sort of life rather than a Monday to Friday sort of dying. (p. 136)

Similarly, according to Ashmos \& Duchon (2000) understanding meaning of work is to recognize the employees as spiritual beings whose souls can be either nurtured or damaged by the work they do. Searching for meaningful work is not all about engaging in a challenging job, but rather doing a job with a purpose, joy, energy and which is a contribution to the society at large (Ashmos \& Duchon, 2000; Milliman et al., 2003). This is explained as a work related dimension of individuals which is spiritual rather than physical or intellectual (Ashmos \& Duchon, 2000).

Moreover, experience of meaningfulness of the task performed was considered as one of the three psychological states by Hackman and Oldham in 1976 when developing their job design model. As they proposed, in order to foster internal motivation where individuals are guided by their own selves rather than some external incentives, three key conditions should be present; knowledge of the results, experience responsibility and experience wok as meaningful (Vroom \& Deci, 1992). The meaningfulness explained here is quite similar to the notion of meaningful work in spirituality discussions. The core job characteristics; Skill variety (the extent that job requires use of diverse skills), Task identity (the extent that job requires completion of identifiable task) and Task significance (the substantial impact the job has on the lives of other people) which generate the meaningfulness of a job are the facets Ashmos and Duchon also incorporated in their above explanation of meaningfulness.

\section{Sense of community}

This is a group or work unit level spirituality dimension which expresses the notion that a spiritual being not only search for meaning of work but also the need to be connected to other human beings. Workplace spirituality exists not only because individuals' expectation to be connected to work that they believe important, but also as a result of their desire to be feel connected to each other at work (Ashmos \& Duchon, 2000). It is the similar sense of community that Mirvis (1997) presented as "relational" qualities that should be there among the individuals at work. Those qualities are reflected by empathy, support, freedom of expres- 
sion and caregiving (Mirvis, 1997; Milliman et al., 2003). From the employee point of view according to Pfeffer (as cited in Jurkiewicz \& Giacalone, 2004) it is one of the important dimensions that they value at work.

The work practices which resulted in isolation among workers under scientific management models have become outdated overtime and the workplace is identified as a community rather than a mechanized entity (Ashmos \& Duchon, 2000). Job designs are much enriched where close supervision is replaced by self-managing teams which encourage individual interactions with each other. Ultimately, the work itself is being rediscovered as a source of spiritual growth and connection to others (Mirvis, 1997). When individuals are bound with caring and respect for each other, they become open to spirit which consequently enhance their morale to contribute more towards the organization (Mirvis, 1997). However, rather than a mere representation, an individual should identify him or herself as a part of the community to gain the benefits of such association (Duchon \& Plowman, 2005).

\section{Alignment with organizational values}

This dimension of workplace spirituality stresses congruence between organizational values and values of individual employees (Milliman et al., 2003; Rego $\&$ Cunha, 2008). The alignment of organizational and individual values occurs when the individual identifies that they have a responsibility towards the society over their self-concept and on the other hand when they believe their organizations act in pursuing common good rather than being selfish in achieving their profit targets (Ashmos \& Duchon, 2000; Milliman et al., 2003; Rego \& Cunha, 2008). Stressing the significance of such alignment, Malphurs (as cited in Milliman et al., 2003) stated that no matter whether the organization is sacred or secular, an individual should not work there if he or she does not share a great degree of the same institutional values. Further, Pfeffer (as cited in Jurkiewicz \& Giacalone, 2004) has identified an individual's ability to live an integrated life where he or she would not encounter role conflict which is one of the four fundamental dimensions of what people seek in workplace. Thereby, a spiritual organization is an entity which creates an environment which facilitates the integration of personal and professional values (Jurkiewicz \& Giacalone, 2004).

When employees experience their personal values are accepted by and similar to that of the organization, they will be adaptable, supportive and committed to the company success, motivated to do their tasks, demonstrate higher levels of organizational based self-esteem and feel personally responsible for success or failure of the organization (Milliman et al., 2003). Citing an example of a company- Ben \& Jerry's- Mirvis (1997) highlighted the employee perception of the social responsibility aspect of value alignment. Accordingly, job satisfaction and commitment to work occurred with the sense of pride of contributing to the social mission of the company and not through material rewards.

\section{Workplace Spirituality and Or- ganizational Commitment}

In the organizational behaviour literature there are studies which have examined the emotional and cognitive side of the organizational life, yet studies to test the spiritual aspect of the workplace is lacking (Duchon \& Plowman, 2005). There is limited number of studies evident in the literature where the construct of workplace spirituality has been studied to find its impact on variables such as organizational performance, organizational commitment, Job satisfaction, Organizational Citizenship behaviour and Job stress. 
Most recent studies on workplace spirituality and organizational commitment are based on the models developed by Ashmos \& Duchon (2000) and Allen \& Meyer (1991). Additions are evident, yet the roots of subsequently developed models can be traced back to them. One of such study is done by Milliman et al. using 200 part-time MBA students in Southwest USA to test the impact of three workplace spirituality dimensions on five workplace attitudes; organizational commitment, intention to quit, intrinsic job satisfaction, job involvement and organization-based self-esteem. In this study, the researchers have ignored the inner life dimension of the original model by Ashmos and Duchon as they did not intend to study transcendent aspect of workplace spirituality as it has more influence on individual's personal life (Milliman et al., 2003). Instead they used the dimension of alignment with organizational values. Organizational commitment also considered as unidimesional, going along with the affective component of commitment. The study concluded that all three spirituality dimensions were significantly related to all job attitude variables including organizational commitment (Milliman et al., 2003).

Rego and Cunha (2008) argued that when people experience workplace spirituality, they tend to feel more affectively attached to their organizations, experience a sense of loyalty towards that organization and feel less instrumentally committed. Here the sense of loyalty and instrumental commitment is referred to normative commitment and continuance commitment respectively. In their study organizational commitment was tested in all three dimensions; affective, normative and continuance and workplace spirituality in five dimensions; team's sense of community, sense of contribution to community, enjoyment at work and alignment with organizational values and opportunities for inner life. According to
Rego \& Cunha (2008), employees will be more affectively and normatively committed and less instrumentally commitmed when the presence of spiritual values is higher in workplace.

Further to this discussion, the link among individual spirituality dimensions and commitment components also can be conceptualized. The developed conceptual model illustrates this individual linkages based on the main dimensions which have been taken into consideration in this study (Figure 5).

Inner life, irrespective of being highly subjective in definition, is proven to have a significant impact on fostering organizational commitment. As mentioned under conceptualizing the spirituality concept, inner life is the expression of one's self and finding the individual identity. An employee finds the job as motivating when he or she has the opportunity to express his or her self, including the spiritual self in the work place (Duchon \& Plowman. 2005). A motivating job consequently creates the attachments towards one's organization which overtime build the affective facet of organizational commitment. As suggested by Meyer \& Allen (1991) self-expression is one of the antecedents of affective commitment which lies within the competence category of work experiences. Continuance commitment which is decided upon the extent of switching costs is also affect significantly by the notion of inner life. As argued by Duchon \& Plowman (2005), expression of one's self is in part an expression of social identity which creates through group membership. Accordingly, when employees perceive that leaving an organization would result in loss of those social interactions and resultant self-expression at work, it creates an unseen emotional cost which binds them to the organization.

Meaningful work also promotes organizational commitment by way of improv- 
ing worker self- esteem, happiness, satisfaction and hope (Rego \& Cunha, 2008). "Happiness" or "enjoyment at work" is considered as one of the major sub themes of meaningful work (Gavin \& Mason, 2004; Rego \& Cunha, 2008) which create productive, motivated and satisfied employees in long run. When employees perceive that their work has a significant impact on organizational performance and can make a difference to the greater community they tend to exert more effort towards the organization and exhibit greater persistence in overcoming obstacles at work (Gavin \& Mason, 2004; Jurkiewicz and Gicalone, 2004; Rego \& Cunha, 2008).
Development of such work attitudes enables employees to bring their entire self to work and perceive job as a part of their life which pave the path to realize their life's goals. Moreover, an obligation or sense of duty develops within the employees and they demonstrate willingness to reciprocate the organization with more committed behaviour (Gavin \& Mason, 2004; Gouldner, 1960; Rego \& Cunha, 2008). This results in a workforce who is more affectively and normatively committed to its organization.

Personal and organizational value alignment also plays an important role in generating commitment. This personorganization fit according to O'Reilly,

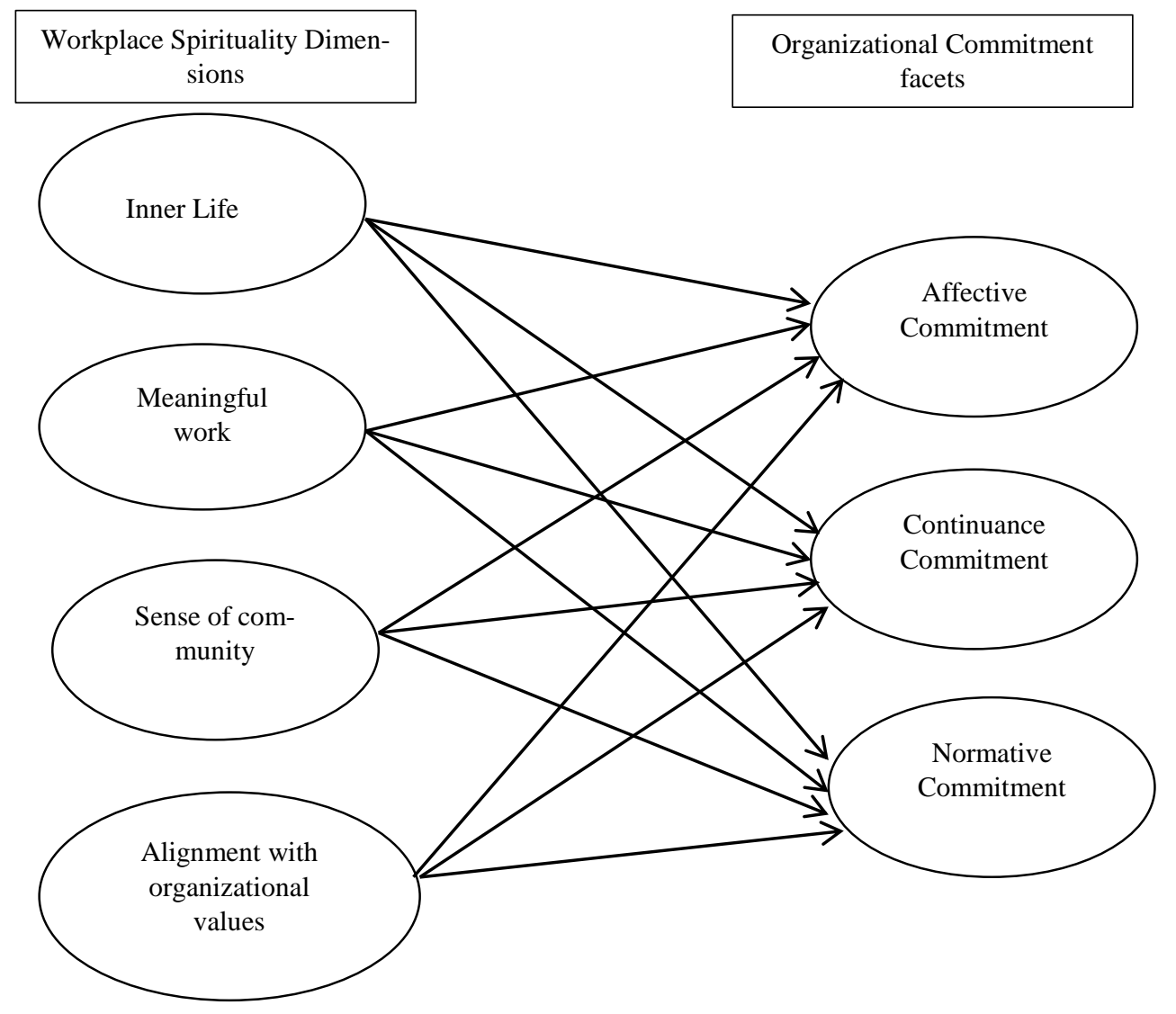

Fig.5 Conceptual model of the Study

Source: author compiled

Chatman and Caldwell and Sims and 
Kroeck (as cited in Rego \& Cunha, 2008) may result in higher satisfaction and stronger affective and normative commitment. When employees feel that their personal goals are not impaired by the organization, but are further enriched and encouraged, they will exhibit more loyalty, honesty, trust and commitment in return (Gouldner, 1960). On the other hand, if the work environment keeps employees away from achieving their personal goals, it will be reflected by higher levels of stress, threatened sense of competency and self-esteem (Gavin \& Mason, 2004) which will ultimately hinder their committed behaviour.

Sense of connection to each other within the organization is also a major enabling condition of organizational commitment. According to Milliman et al., (2003) having a strong sense of community is related to greater employee commitment and higher retention rates. Similarly, reflected as "Mutuality" in the Jurkiewicz and Giacalone's Values Framework of workplace Spirituality, it asserts that "all employees are interconnected and mutually dependent, each contributes to the final output by working in conjunction with others" (p. 131) which result in organizational commitment, job satisfaction and self-esteem (Milliman et al., 2001). This "affiliation" is one of the personal dispositions which antecede affective component of commitment (Meyer \& Allen, 1991). It exerts normative pressures on an individual through socialization following the entry to the organization and consequently the personal relationships that are built through the socialization act as a side-bet which generates continuance commitment behaviour (Meyer \& Allen, 1984, 1991; Wiener, 1982). In the modern organizational context where workplace is considered as major source of an individuals' interpersonal, social and political relationships (Gavin \& Mason, 2004), employees find that loss of relationships had within the organization as a significant cost of leaving the employment.

\section{Conclusion}

Workplace spirituality has become an appealing topic as the modern organizations recognize the importance of spiritual values in enhancing the performance of its employees and mitigating the harmful actions to human soul such as mental harassment, humiliation and destruction, dehumanized practices and vassalage (Rego \& Cunha, 2008). When people bring only their arms and brains to the workplace without their souls, it hinders the employees' ability to utilize his or her full potential at work and creativity, causes emotional disruption due to the collision of work and personal life, alienation and disparity from their working environment, result in higher turnover, absenteeism and negligent behaviour (Rego \& Cunha, 2008) which consequently reduces affective and normative commitment. This creates an instrumentally committed workforce from which organizations cannot expect a performance beyond what employees get from the organization.

If the employer's only concern is to improve the retention rates of the employees, then identifying different facets of commitment might be irrelevant. In such scenario commitment will only be seen in its general form which is the feeling of belongingness or attachment towards the organization. But in macro level retention of the workforce is not the only determinant of higher organizational performance. The quality of the final output, loyalty towards the organization, harmonious work setting, group cohesion, motivated behaviour are also playing a critical role in deciding overall organizational success. In order to reap such benefits, organizational commitment should be analyzed in depth to identify the varying psychological states- affective, continuance and normative behind it. Spiritual 
values, as discussed in this paper provide a facilitative platform to enhance these psychological states by tapping the inner self of the individual employees. Spiritual values within the workplace give the opportunity for the individuals to be their own self within the work place and to give their maximum contribution towards it.

However, establishing a culture that values expression of self, provide meaningful work, foster group membership and establish an alignment between personal and organizational goals in a workplace is a challenge where organizations are required to go through a gradual change process. This change is not without cost, especially as it demands a change in leadership and organizational culture. According to Polly et al. (2005) spirituality if not managed properly can become an instrument of manipulation of employees' efforts and can become a source of disunity due to individual differences in acceptance of spiritual values. It requires training the employees on basic skills to accept diversity and appreciative listening, rewarding actions led by spiritual values, make religion to be a vehicle to bring out spiritual values to the organization and encourage a work place where employees, too have a fair share of the gains. Organizations should select whether they are going to accommodate spiritual values or encourage spirituality at work place. Long lasting benefits of spirituality can only be gained by encouraging a spiritually rich community within the workplace (Polly et al., 2005). Accordingly, employer should accept the fact that embedding spirituality will not be without cost or conflicts. Thus, as proposed so far, accepting spirituality at workplace is a sort of psychological orientation towards understanding and enhancing organizational commitment. It will create a win-win scenario where not only employees and organization but also society at large will reap the benefits.

\section{References}

Adeyemo, D. (2007). Emotional Intelligence and the relationship between Job Satistfaction and Organizational Commitment of empoyees in Public Parastatals in Oyo state, Nigeria. Pakistan Journal of Social Sciencs, 4(2), 324-330

Allen, N. J., \& Meyer, J. P. (1990). The Measurement and antecedents of affective, continuance and normative commitment to the organization. Journal of Occupational Psychology, 1-18,doi: $10.1111 / \mathrm{j} .2044-$ 8325.1990.tb00506.x

Ashmos, D. P., \& Duchon, D. (2000). Spirituality at Work: A Conceptualization and Measure. Journal of Management Inquiry, 9, 134-145,doi: $10.1177 / 105649260092008$

Banyhamdan, K., Harrim, H., \& AlQotop, M. (2012). Transforming an Organization into a Spiritual One:A Five-Pathway Integrated Framework. International Journal of Business Management, 7(11), 74-86, doi: 10.5539/ijbm.v7n11p74

Becker, H. (1960). Notes on the Concept of Commitment. American Journal of Sociology, 66, 32-42, doi: $10.1086 / 222820$

Brown, R. (1996). Organizational Commitment: Clarifying the concept and simplifying the existing construct typology. Journal of Vocational Behaviour(49), 230-251, doi: $10.1006 /$ jvbe. 1996.0042

Buchanan, B. (1974). Building Orgnizational Commitment: The Socialization of managers in Work organizations. Administrative Science Quarterly, 19, 533-546 
Campbell, J., \& Hwa, Y. (2014). Workplace Spirituality and organizational Commitment influence Job Performance among Academic staff. Journal Pengurusan, 115-123.

Cavanagh, G. (1999). Spirituality for Managers: Context and Critique. Journal of Organizational Change Management, 12, 186-199, doi: 10.1108/09534819910273793

Dehaghi, M. R., Goodarzi, M., \& Arazi, Z. K. (2012). The effect of spiritual values on employees' organizational commitment and its models. Social and behavioural Sciences (pp. 159166). Elsevier Ltd, doi: 10.1016/j.sbspro.2012.09.025

DeShon, R., \& Landis, R. (1997). The Dimesionality of the Hollenbeck, Williams and Klein (1989) measure of goal commitment on complex tasks. Organizational Behaviour and Human Decision Processes, 70, 105116 , doi:https://doi.org/10.1006/obhd.1997 .2699

Djafri, F., \& Noordin, K. (2017). The Impcat of workplace spirituality on organizational commitment: A case study of Takaful Agents in Malasiya. Journal of Humanomics, 33(3), 384396,doi: 10.1108/H-02-2017-0018

Duchon, D., \& Plowman, D.A. (2005). Nurturing the spirit at work: Impact on work unit performance. The Leadership Quarterly, 16(5), 807-833, doi: 10.1016/j.leaqua.2005.07.008

Gavin, J., \& Mason, R. (2004). The Virtuous organization: The Value of Happiness in the Workplace. Organizational Dynamics, 33(4), 379392, doi:10.1016/j.orgdyn.2004.09.005
Gouldner, A. (1960). The norm of reciprocity: a preliminary statement. American Sociological Review, 25(2), 161-178, doi: 10.2307/2092623

Jayarathna, S. (2016). Organizational Commitment: A case in Academia. Internatonal Journal of Academic Research and Development, 1(7), 4045

Jurkiewicz, C., \& Giacalone, R. (2004). A values Framework for Measuring the Impact of workplace Spirituality on Organizational Commitment. Journal of Business Ethics(49), 129142, doi: 10.1023/B:BUSI.0000015843.22195 .b9

Kalantarkousheh, S., Sharghi, N., Sloemani, M., \& Ramezam, S. (2013). The Role of Spiritual Intelligence on Organizational Commitment in Employees of Universities in Tehran Province, Iran. Social and Behavioural Sciences, 499-505, doi:10.1016/j.sbspro.2014.04.460

Khatri, P., \& Gupta, P. (2017). Workplace Spirituality: A Predictor of Employee Wellbeing. Asian Journal of Management, 8(2), 284-292, doi:10.1016/j.sbspro.2014.04.460

Kinjerski, V. M., \& Skrypneck, B. (2004). Defining Spirit at work:finding common ground. Journal of Organizational Change Management, 17(1), 26-42, doi: 10.1108/09534810410511288

Kinjerski, V., \& Skrypnek, B. (2006b). Creating Organizational conditions that foster employee spirit at work. Leadership \& Organization Developement Journal, 27(4), 280295, doi: $10.1108 / 01437730610666037$ 
Krishnakumar, S., \& Neck, C. (2002). The "What", "Why" and "How" of Spirituality in the Workplace. Journal of Managerial Psychology, 17(3), 153-164, doi:10.1108/02683940210423060

Liu, C., \& Robertson, P. (2011). Spirituality in the Workplace: Theory and Meausrement. Journal of Management Inquiry, 20(1), 35-50, doi: $10.1177 / 1056492610374648$

Locke, E., Latham, G., \& Erez, M. (1988). The diterminants of Goal commitment. Academy of Management Review, 13, 23-39, doi: 10.5465/amr.1988.4306771

Luthans, F. (2006). Organizational Behaviour: Business \& Economics. McGraw Hill/Irwin.

Meyer, J., \& Allen, N. (1984). Testing the "Side-Bet Theory" of Organizational Commitment: Some Methodological Considerations. Journal of Applied Psychology, 69(3), 372-378, doi:10.1037/00219010.69.3.372

Meyer, J., \& Allen, N. (1991). A ThreeComponent Conceptulization of Organizational Commitment. Human Resource Management Review, 1(1), 61-89, doi: 10.1016/10534822(91)90011-Z

Meyer, J., \& Herscovitch, L. (2001). Commitment in Workplace: Toward a general model. Human Resource Management Review, 11(3), 299-326, doi: 10.1016/S1053-4822(00)00053-X

Milliman.J., Czaplewski, A., \& Ferguson, J. (2003). Workplace Spirituality and employee work aatitudes: An exploratory empirical assessment. Journal of Organizational Change Management, 16(4), 426-447, doi: 10.1108/09534810310484172
Mirvis, P. (1997). Crossroads-"Soul Work" in Organizations. Organization Science, 8(2), 192-206, doi:10.1287/orsc.8.2.192

Pandey, A. (2017). Workplace Spirituality: Themes, Impact and Research Directions. South Asian Journal of Human Resources Management, 4(2), 1-6, doi: $10.1177 / 2322093717732630$

Polley, D., Vora, J., \& SubbaNarasimha, P. (2005). Paying the devil his due:Limits and Liabilities of Workplace Spirituality. International Journal of Organizational Analysis, 13(1), 50-62, doi: 10.1108/eb028997

Rego, A., \& e Cunha, M. P. (2008). Workplace spirituality and organizational commitment: an empirical study. Journal of Organizational Change Management, 21, 53-75, doi: $10.1108 / 09534810810847039$

Rusbult, C., \& Farrell, D. (1983). A longitudinal test of the investment model: the impact on job satisfaction, job commitment and turnover of variations in rewards, costs, alternatives and investments. Journal of Applied Psychology(68), 429-438, doi:10.1037/0021-9010.68.3.429

Scholl, R. (1981). Differentiating Commitment From Expectancy as a Motivating Force. Academy of Management Review, 6, 589-599, doi: 10.5465/amr.1981.4285698

Shepherd, J., \& Mathews, B. (2000). Employee Commitment: Academic Vs. Practitioner perspectives.

Employee Relations, 22(6), 555-575, doi: 10.1108/01425450010379199

Steers, R.M. (1977). Antecedents and Outcomes of Organizational Commitment. Administrative Science 
Quarterly, 22(1), 46-56, doi: $10.2307 / 2391745$

Vasconcelos, A. (2018). Workplace

Spirituality: Empirical evidence revisited. Management Research Review, 41(7), 789-821, doi:10.1108/MRR-07-2017-0232

Vroom, V., \& Deci, E. (1992). Management and Motivation: Selected Readings (2nd ed.). Penguine Books.

Wainaina, L., Iravo, M., \& Waititu, A. (2014). Workplace Spirituality as a Determinant of Organizational Commitment amongest Academic Staff in the Private and Public
Universities in Kenya. Interntional Journal of Academic research in Business and Social Sciences, 4(12), 280-293

Wiener, Y. (1982). Commitment in Organizations:A normative view. Academy of Management Review, 7, 418-428,doi:

10.5465/amr.1982.4285349

Yousef, D. (2000). Organizational

Commitment as a mediator of relationship between Islamic work ethic and attitudes toward organizational change. Human Relations, 53(4), 513-537, doi: $10.1177 / 0018726700534003$ 